\title{
Neuroligin 4, X-Linked
}

National Cancer Institute

\section{Source}

National Cancer Institute. Neuroligin 4, X-Linked. NCI Thesaurus. Code C75747.

Neuroligin-4, X-linked (816 aa, $\sim 92 \mathrm{kDa}$ ) is encoded by the human NLGN4X gene. This protein may play a role in synapse formation. 